Creative Commons User License: CC BY-NC-ND

Abstracted by: EBSCOhost, Electronic Journals Service (EJS), Google Scholar, Journal Seek, Scientific Commons,

Food and Agricultural Organization (FAO), CABI and Scopus
Journal of Agricultural Extension

Vol. 23 (2) April, 2019

ISSN(e): 24086851; ISSN(Print); 1119944X

http://journal.aesonnigeria.org

http://www.ajol.info/index.php/jae

Email: editorinchief@aesonnigeria.org

http://eoi.citefactor.org/10.11226/v23i2

\title{
Rice Farmers Preferred Extension Teaching Methods for Capacity Building in Kwara State, Nigeria
}

https://dx.doi.org/10.4314/jae.v23i2.2

\section{Ayanda, Ibrahim Folorunsho}

Department of Agricultural Economics and Extension Services, College of Agriculture, Kwara State University, Malete, PMB 1530, Ilorin, Nigeria. E-mail Address: iayanda@yahoo.com, Phone: 08033737391

Abstract

The study investigated rice farmers preferred teaching methods for capacity building. A three stage sampling procedure was used to select 130 small scale rice farmers. Results revealed that the average age of farmers was 38.97 years. The commonly used extension methods by rice farmers include farm and home visit (88.42\%), management training plot (93.11\%), small plot adoption techniques (60.12\%), on farm adaptive research (68.13\%), farmers field Days (54.62\%) and radio (13.85\%). Seventy-five percent of the rice farmers preferred MTP due to its size, $72 \%$ for acquisition of new skills, $65 \%$ and $61 \%$ for enhance capacity on integrated pest and weed management respectively. Results show that on the average $93.11 \%$ of the rice farmers agreed that characteristics of the teaching methods such as size, period of stay on the field, allowance for participation and evaluation made MTP more relevant than other methods for capacity building of rice farmers. It was recommended that extension organizations should promote the use of MTP as it allows farmers to acquire skills in existing and emerging rice production innovations.

Key words: skill acquisition,' participation, and evaluation

\section{Introduction}

The contribution of agriculture to Nigeria's gross domestic product (GDP) remains unimpressive as it contributes $25.52 \%$ to the nominal GDP of the country (Nigerian Bureau of Statistics, 2018) This is connected with low agricultural productivity partly due to poor access to improved technologies by farmers. Oriakhi and Okoedo-Okojie (2013) report that poor access to agricultural information hindered adoption of improved technologies with attendant consequences of poor performance of the agricultural sector. This has implication on food security and perpetration of poverty among farmers. Adoption of improved farm practices requires adequate information, which has to be effectively disseminated using the devices preferred by most of the clienteles. Selection of devices is dictated by the size and type of audience, and the characteristics of the innovation to be disseminated. There is an urgent need for policy and institutional interventions to ensure that Nigerian small scale farmers (SSRFs) enjoy uninterrupted access to knowledge and skills at the right time. The consensus is that agriculture has the capability to meet the food needs of the world's 8-10 billion people while substantially decreasing the proportion of population who are hungry. (Valentine, 2018).

Extension teaching methods are devices, modes or channels used to create situations in which new information can pass freely from the source (extension worker or research institutes) to the farming communities. Appropriate extension methods which provide adequate opportunities for farmers to learn and that stimulate mental and physical activities should be used at all times. There is a consensus that people learn by seeing, doing and hearing. 
Creative Commons User License: CC BY-NC-ND

Abstracted by: EBSCOhost, Electronic Journals Service (EJS), Google Scholar, Journal Seek, Scientific Commons,

Food and Agricultural Organization (FAO), CABI and Scopus
Journal of Agricultural Extension

Vol. 23 (2) April, 2019

ISSN(e): 24086851; ISSN(Print); 1119944X

http://journal.aesonnigeria.org

http://www.ajol.info/index.php/jae

Email: editorinchief@aesonnigeria.org

Rice is one of the crops selected by various tiers of government in Nigeria for mass production because of its food value, income generation potential and in providing foreign exchange earnings. Rice is a staple food for more than fifty percent of the world population and ranks third after wheat and maize in production (Muhammad et al. 2013). In Nigeria, rice consumption has risen tremendously, usually served during religious and social gatherings. It has also become important as a daily dietary feeding stuff. Its consumption cuts across sex, age, tribe and religion. Consumption of rice is also on the increase because of ease of preparation by members of households. Although Nigeria has resources to produce adequate quantity and quality of rice for consumption, however the existing farmers' skill, knowledge, and equipment are grossly inadequate to support the production of about 6 million tonnes of rice required per annum. The attainment of this production level is only feasible if the farmers duly access requisite skills, knowledge and equipment or machine that can ease the rice value chain.

Nigeria annual rice demand is about 6 million tonnes, out of which only about 3 million tonnes is being produced locally. The supply gap of about 2.79 million tonnes (about $56 \%$ of demand) is bridged by importation (FAO, 2018). Nigeria is the highest importer of rice in Africa, and the second in the world. Unfortunately, the country has multifarious and unutilized natural resources (land and water) capable of supporting massive production of the crop. Even countries such as Thailand, India, and Vietnam with similar comparable advantages for rice production produced around 9.5, 9.5 and 7 million metric tons of rice respectively annually. The over dependency on importation of rice is undesirable and unacceptable as importation of this commodity is now a conduit pipe through which the nation's foreign exchange earnings is being siphoned to create job and economic prosperity for other nationals at the expense of the economic growth of the indigenous farmers. Massive importation of food, especially, rice, wheat, sugar and fish, has continued to bleed the nation's economy, with the four items accounting for a whopping N1 trillion loss to the nation annually (Abubakar, 2016).

Technological change has been the major driving force for increasing agricultural productivity and promoting agriculture development in all the Organizations for Economic Co-operation and Development (OECD). In addition, agricultural development depends on innovation. Innovation is a major source of improved productivity, competitiveness and economic growth throughout advanced and emerging economies and plays an important role in creating jobs, generating income, alleviating poverty and driving social development. Thus, if farmers and even the nations are to cope, compete and thrive in the midst of changes in agriculture and economy they must innovate continuously (OECD, 2015). Over many decades, policies for agriculture, trade, research and development, education, training and advice have been strong influences on the choice of technology. The level of agricultural production and farm practices. Farmers have always looked to new technologies as a way to reduce costs. In addition, higher incomes, greater knowledge and improved channels of communication are leading consumers to demand low-cost food of higher quality increasingly produced through organic methods in many countries, with more variety, consistency and year-round availability. At the same time, consumers are increasingly demanding that their food be produced using techniques that conserve natural resources, limit environmental pressures and pay greater attention to rural viability and animal welfare.

Omofonmwan and Kadiri (2017) report that rice production is plagued by myriads of problems including; inadequate knowledge on use of herbicides, pesticides, postharvest handling, processing, marketing, pest and diseases as well as inadequate extension services. These 
Creative Commons User License: CC BY-NC-ND

Abstracted by: EBSCOhost, Electronic Journals Service (EJS), Google Scholar, Journal Seek, Scientific Commons,

Food and Agricultural Organization (FAO), CABI and Scopus
Journal of Agricultural Extension

Vol. 23 (2) April, 2019

ISSN(e): 24086851; ISSN(Print); 1119944X

http://journal.aesonnigeria.org

http://www.ajol.info/index.php/jae

Email: editorinchief@aesonnigeria.org

demand that appropriate devices must be used to transfer appropriate technology to the small scale rice farmers who constituted the majority of rice growers in the country. The use of appropriate and preferred extension teaching methods or channels will assist the farmers tremendously to overcome the skill and knowledge deficiencies of the small scale rice farmers. Also this prevailing skill gaps explains the gap between what farmers produce from improved seed varieties and what the varieties were developed to produce on the farmers' field.

Purpose of the study

The main objective of the study was to investigate the preferred extension teaching methods for capacity building of small scale rice farmers. The specific objectives were to:

- describe the socio-economic characteristics of SSRFs;

- identify the teaching methods used by extension organizations;

- identify characteristics of the methods relevant to capacity building; and

- identify the up-scaled capabilities of SSRFs consequent upon the use of the teaching methods.

\section{Methodology:}

The study was carried out in Kwara State, Nigeria. The State falls within Latitudes $11^{0} 2^{1}$ and $11^{0}$ $45^{1}$. It is sandwiched between longitudes $2^{0} 45^{1}$ and $6^{0} 40^{1}$ East of the Greenwich Meridian. The State has 16 local government areas (LGAs). It is bounded in the West by Benin Rep However, the State is blessed with many perennial rivers including Rivers Niger, Osin, Oyi, with alluvial running into several hectares of land suitable for rice production. This makes Kwara State to have comparative advantage for rice production. The population of Kwara State is 2, 365,353 (Nigerian Population Commission, 2006). However, IndexMundi (2017) reports a population growth rate of 2.43 for Nigeria. Thus, the population of Kwara State by the end of 2018 may be closer to 2.7million people. More than half of the inhabitants of the state depend on agriculture as means of livelihood.

The population for the study consisted of all rice farmers in the State. The study used a three stage sampling technique in selecting respondents. Stage one involved a purposive selection of Zone B, an administrative Zone of Kwara Agricultural Development Project (ADP) where rice production is prominent. The second stage involved a random selection of $25 \%$ of extension cells in the zone. Thus ten extension cells out of existing 40 were selected. The extension cells selected include Lafiagi I, Lafiagi II, Sharagi I, Sharagi II, Bacita I, Bacita II, Lade I, Lade II, Kpada I and Rogun I. With the assistance of the extension agents (EAs) in charge of these cells, sample frames containing the lists of rice farmers in each cell were obtained. Thus, $5 \%$ of rice farmers in the selected cells were proportionately and randomly selected. These added up to 130 rice farmers used as respondents. Data were collected by means of validated structured interview schedule. Results were presented using frequency counts, percentage scores and charts.

The age of the rice farmers was measured in years. Similarly, respondents were asked to tick the appropriate level of education attained from the lists of alternatives including: no formal education, adult education, Quranic education, primary school, junior secondary school, senior secondary school /grade II teachers' certificate and tertiary education. Also, respondents were asked to indicate the size of their household. Farm ownership system was determined by asking respondents to select from lists of alternatives including rent, inheritance, leasehold and purchase. The farm size was measured in hectares or heaps which was also converted into hectares. Years of experience in rice production was captured by asking respondents to state the number of years spent in rice production. Rice yield was measured in kilograms/tonnes/baskets/pick-ups. However, 
Creative Commons User License: CC BY-NC-ND

Abstracted by: EBSCOhost, Electronic Journals Service (EJS), Google Scholar, Journal Seek, Scientific Commons,

Food and Agricultural Organization (FAO), CABI and Scopus
Journal of Agricultural Extension

Vol. 23 (2) April, 2019

ISSN(e): 24086851; ISSN(Print); 1119944X

http://journal.aesonnigeria.org

http://www.ajol.info/index.php/jae

Email: editorinchief@aesonnigeria.org

the yield was eventually converted into tonnes/hectare for uniformity while income realized from rice production on annual basis was presented in Naira.

Through the extension agents in each of the selected extension cells, the commonly used extension methods to disseminate information by extension organizations in the study area were examined. As part of steps to determine the appropriateness of the channels, respondents were asked to assess characteristics of the teaching methods which include size (where applicable) which will make the channel to be visible and attractive to the rice farmers; extent to which the channel allows for participation which will give room for the farmers to be involved in the planning, demonstration and practice of the innovations. The number of farmers on each of the characteristics will be expressed as a percentage of sample size. A percentage score of less than $50 \%$ indicate the specific characteristic of the teaching method will not be supportive to up scaling of capacities of the farmers. A 3 point Likert-type scale was used to measure the skill acquired by respondents, consequent upon use of the teaching methods. Respondents were requested to state if they strongly agreed, moderately agreed or disagreed on the acquisition of selected skills through the teaching methods. The level of agreement (in percentages) was presented with piechart.

\section{Results and Discussions:}

\section{Socio-economic characteristics of respondents}

Table 1 shows that more than half $(57 \%)$ of respondents fell within the age bracket of $31-$ 40 , the average age was 38.97 years. The average was less than the average age (49.4 years) of rice farmers reported in Ekiti State (Mohammed-Lawal, 2012). It was deduced that youths were venturing into rice production more than in the past. The involvement of the energetic and venturesome youths could accelerate production on a sustainable basis in Nigeria.

Results (Table 1 ) also reveals that the majority $(86.15 \%)$ of the respondents are male. Rice production is an energy demanding activity. However, if mechanization is available and affordable, females' participation in rice production could improve. In the same vein, the majority $(90 \%)$ of the rice farmers were married. This could be to secure cheap family labour for rice production activities. Results show that $11.57 \%$ and $43 \%$ of the rice farmers acquired tertiary and secondary school education respectively. Adoption of innovations by firms and workers is an important part of the process of

technological change. Many prior studies find that highly educated workers tend to adopt new technologies faster than those with less education (Riddle et.al., 2012). It could be inferred that possession of formal education by the respondents will provide appropriate platform to be aware, try and agitate to learn new skills on rice production through appropriate teaching method. This will make them have right attitude to improved technology or programmes that will improve their capabilities on sustainable basis.

Table 1 also shows that the majority (79.2\%) of the respondents recorded yield of 3-4 with an average of 3.34 tons of paddy rice/hectare. This level of output was an improvement over the rice yield of 1.62, 1.84, 2.70 and 2.60 tons/hectare reported in 1997, 1998, 1999, and 2000 respectively, (Kwara ADP, CAYS Report, 2015). This result may suggest that exposure of farmers to innovations on rice production by Kwara ADP and other agencies had impacted positively on rice production. It is overt that this level of production is grossly lower than the world average yield of 4.57 tonnes per hectare (that is, 496.6 million tonnes 
Creative Commons User License: CC BY-NC-ND

Abstracted by: EBSCOhost, Electronic Journals Service (EJS),

Google Scholar, Journal Seek, Scientific Commons,

Food and Agricultural Organization (FAO), CABI and Scopus

http://eoi.citefactor.org/10.11226/v23i2

milled basis from 162.9 million hectares of rice farm) in 2014 (Food and Agricultural Organizations of the United Nations, 2014). Therefore, continuous exposure of Nigerian small scale farmers to innovations through appropriate channel will increase rice production in Nigeria.

\section{Table 1: Rice farmers' socio-economic characteristics}

\begin{tabular}{|c|c|}
\hline Socio-economic Characteristics & Percentage (\%) \\
\hline \multicolumn{2}{|l|}{ AGE (in years) } \\
\hline $\begin{array}{l}<30 \\
31-40 \\
41-50 \\
\text { Above } 51\end{array}$ & $\begin{array}{l}16.15 \\
43.85 \\
26.92 \\
13.08\end{array}$ \\
\hline \multicolumn{2}{|l|}{ Sex } \\
\hline $\begin{array}{l}\text { Male } \\
\text { Female } \\
\text { Marital status }\end{array}$ & $\begin{array}{l}86.15 \\
13.85\end{array}$ \\
\hline $\begin{array}{l}\text { Single } \\
\text { Divorced/separated } \\
\text { Widowed } \\
\text { Married }\end{array}$ & $\begin{array}{c}3.85 \\
2.30 \\
3.85 \\
90.00\end{array}$ \\
\hline \multicolumn{2}{|l|}{ Number of households } \\
\hline $\begin{array}{l}1-5 \\
6-10 \\
11-15 \\
16 \text { and above } \\
\text { Average }\end{array}$ & $\begin{array}{c}31.4 \\
36.3 \\
29.4 \\
2.9\end{array}$ \\
\hline $\begin{array}{l}\text { Head of household } \\
\text { Yes } \\
\text { Level of education }\end{array}$ & 88.46 \\
\hline $\begin{array}{l}\text { No formal education } \\
\text { Adult education } \\
\text { Quranic education } \\
\text { Primary sch. } \\
\text { Junior secondary sch. } \\
\text { Senior secondary sch. } \\
\text { Tertiary Education } \\
\text { Yield in tons/hectare }\end{array}$ & $\begin{array}{r}7.69 \\
4.62 \\
15.38 \\
20.77 \\
19.92 \\
23.08 \\
11.54\end{array}$ \\
\hline$<1$ & - \\
\hline $1-2$ & 19.3 \\
\hline $3-4$ & 79.2 \\
\hline $5-6$ & 1.5 \\
\hline $7-8$ & - \\
\hline Average yield & 3.34 \\
\hline Total & 100 \\
\hline
\end{tabular}

Source: Field Survey, 2017. 
Creative Commons User License: CC BY-NC-ND

Abstracted by: EBSCOhost, Electronic Journals Service (EJS), Google Scholar, Journal Seek, Scientific Commons,

Food and Agricultural Organization (FAO), CABI and Scopus
Journal of Agricultural Extension

Vol. 23 (2) April, 2019

ISSN(e): 24086851; ISSN(Print); 1119944X

http://journal.aesonnigeria.org

http://www.ajol.info/index.php/jae

Email: editorinchief@aesonnigeria.org

Figure 1 indicates that less than half (44.67\%) of the rice farmers had 21-30 years of rice farming experience. The average was 21.12 years. The findings show that the information elicited from the respondents will be reliable and can be used for policy and strategies development on the use of appropriate devices for information dissemination to farmers. The result showed that most (79.8\%) of the small scale rice farmers (SSRFs) operated1-2 hectares with an average farm size of 2.6 hectares. This was higher than the national average farm size of 0.57 hectares. Larger farm size is a factor in adoption of innovation and will predispose the farmers to acquire more knowledge through the extension teaching methods. This agreed with Thomas et al. (2017) that farm size plays a critical role in adoption process of a new technology. The adoption of technology by farmers is affected by farm size and other factors influencing adoption affect farm size. Some technologies are termed as scale-dependant because of the great importance of farm size in their adoption. Farmers with large farm size are likely to adopt a new technology as they can afford to devote part of their land to try new technology unlike those with less farm size.

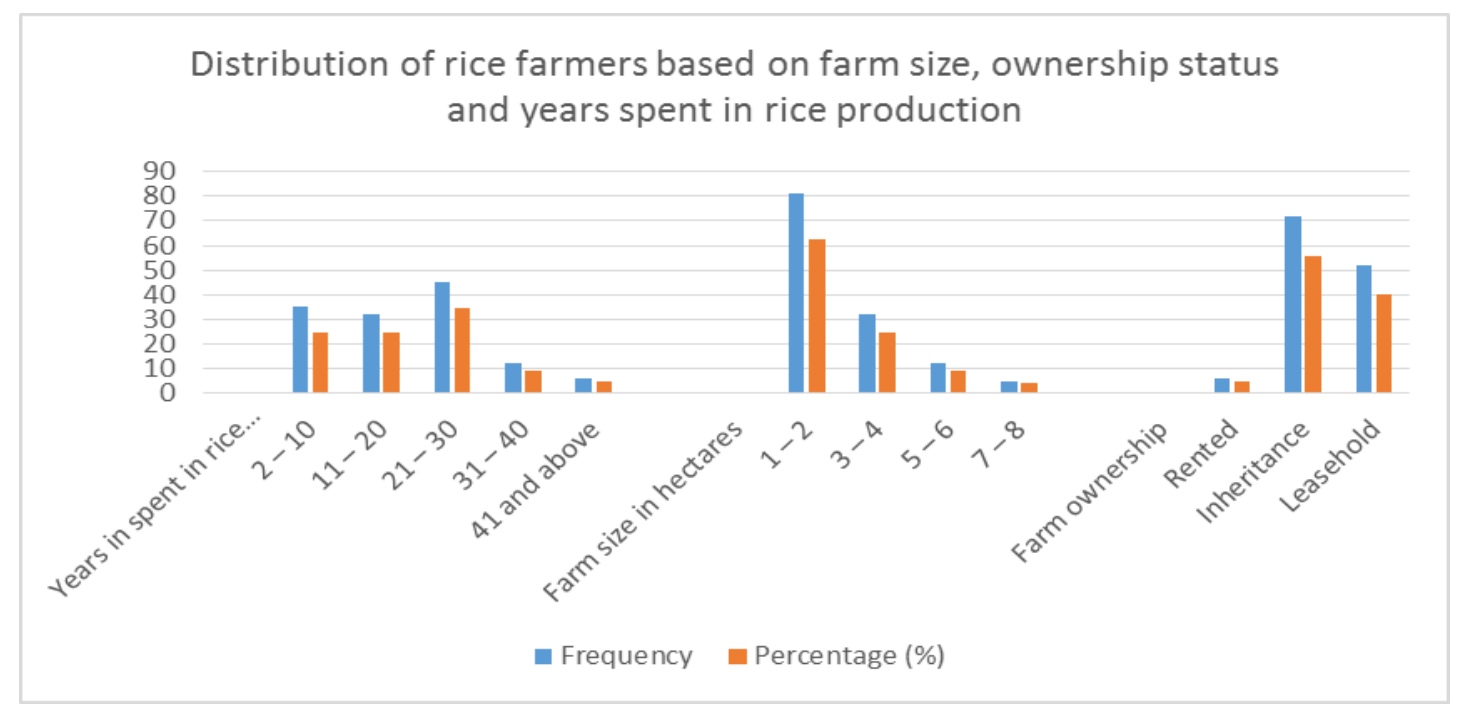

Source: Field Survey, (2017).

\section{Characteristics of Extension Teaching Methods Used}

The characteristics and various types of teaching methods commonly used by extension organizations are presented in Table 3. The teaching methods commonly used include management training plot (MTP) (93.11\%), On farm adaptive research $(68.12 \%)$ and small plot adoption techniques $(60.12 \%)$, farm and home visits $(88.46 \%)$, leaflets $(10.72 \%)$, farmers field days $(54.62 \%)$, radio and television. Based on the criteria used, the aggregate mean score shows that the majority $(93.46 \%)$ of the respondents rated MTP as the most relevant channel for innovation dissemination. This shows that MTP was highly favoured for capacity building of small scale rice farmers. In this respect, it is incumbent on the extension organizations to adopt this device when presenting innovation designed to enhance the capabilities of rice farmers. MTP is a teaching method that many farmers can share and recoup the cost of implementation. Now that the funding of ADPs in the country is dwindling, it becomes imperative to use a sustainable teaching method. 
Creative Commons User License: CC BY-NC-ND

Abstracted by: EBSCOhost, Electronic Journals Service (EJS), Google Scholar, Journal Seek, Scientific Commons,

Food and Agricultural Organization (FAO), CABI and Scopus

http://eoi.citefactor.org/10.11226/v23i2
Journal of Agricultural Extension

Vol. 23 (2) April, 2019

ISSN(e): 24086851; ISSN(Print); 1119944X

http://journal.aesonnigeria.org

http://www.ajol.info/index.php/jae

Email: editorinchief@aesonnigeria.org

Table 3: Extension teaching methods based on characteristics relevant to capacity building Extension Teaching Methods

Characteristics

\begin{tabular}{|c|c|c|c|c|c|c|}
\hline & $\begin{array}{l}\text { Size: } \\
\text { Attractive to } \\
\text { farmers (\%) }\end{array}$ & $\begin{array}{l}\text { Adequate period } \\
\text { of stay on the } \\
\text { field } \\
(\%)\end{array}$ & $\begin{array}{l}\text { Participatory } \\
(\%)\end{array}$ & $\begin{array}{l}\text { Possibility } \\
\text { of } \\
\text { evaluation } \\
(\%)\end{array}$ & $\begin{array}{l}\text { Recoupin } \\
\mathrm{g} \text { cost of } \\
\text { impleme } \\
\text { ntation }\end{array}$ & $\begin{array}{l}\text { Average } \\
\text { rating } \\
(\%)\end{array}$ \\
\hline $\begin{array}{lcc}\text { Demonstrations: } & \text { Small } & \text { Plot } \\
\text { Adoption Technique } & \text { (SPAT) } & \end{array}$ & 26.92 & 77.69 & 66.92 & 96.92 & 34.71 & 60.12 \\
\hline Management Training Plot (MTP) & 90.00 & 89.23 & 96.92 & 97.69 & 91.72 & 93.11 \\
\hline $\begin{array}{l}\text { On farm Adaptive Research } \\
\text { (OFAR) }\end{array}$ & 20.77 & 93.08 & 88.46 & 94.61 & 46.23 & 68.63 \\
\hline Farm and Home Visits & - & - & 87.69 & 89.23 & - & 88.46 \\
\hline Field Days & - & - & 74.62 & 34.62 & - & 54.62 \\
\hline Leaflets & - & 10.72 & - & - & - & 10.72 \\
\hline Radio & - & - & 11.55 & 16.15 & - & 13.85 \\
\hline Television & - & - & 9.72 & 12.10 & - & 10.91 \\
\hline
\end{tabular}

Source: Field Survey, 2017

\section{Skills Acquired from Different Teaching Methods}

Figure. 2, shows that $82 \%$ and $78 \%$ of the respondents strongly agreed that their capabilities in integrated weed and pest management were enhanced respectively. The implication was that application of appropriate teaching method provided the opportunity for the rice farmers to acquire integrated weed and pest control techniques. These might have contributed to the increased yield of rice recorded in the study area consequent upon effective and efficient techniques for their control. Therefore, there is a ray of hope for the country in meeting the rice needs of the citizens. Effective weed and pest control will reduce the staggering losses of crops on the field and produce in storage put at between 20 to $40 \%$ (Oni, 2014). With this development it could be asserted that sustainable rice production in Nigeria is attainable. Similarly, $67 \%, 61 \%$ and $58 \%$ of the small scale rice farmers strongly agreed that they acquired new skills in planting distance for arable crops, herbicide application and types of suitable fertilizer for various arable crops. The planting distance allowed the farmers to optimize the use of land resources by securing optimum plant population. Skills in the use of herbicide will guarantee effective weed control and reduce to the barest minimum weed competition with the crop for space, nutrient and water.

Application of wrong type of fertilizer and timeliness of application are factors that play important functions in rice yield and revenue generation to the farmers and government. 
Creative Commons User License: CC BY-NC-ND

Abstracted by: EBSCOhost, Electronic Journals Service (EJS),

Google Scholar, Journal Seek, Scientific Commons,

Food and Agricultural Organization (FAO), CABI and Scopus
Journal of Agricultural Extension

Vol. 23 (2) April, 2019

ISSN(e): 24086851; ISSN(Print); 1119944X

http://journal.aesonnigeria.org

http://www.ajol.info/index.php/jae

Email: editorinchief@aesonnigeria.org

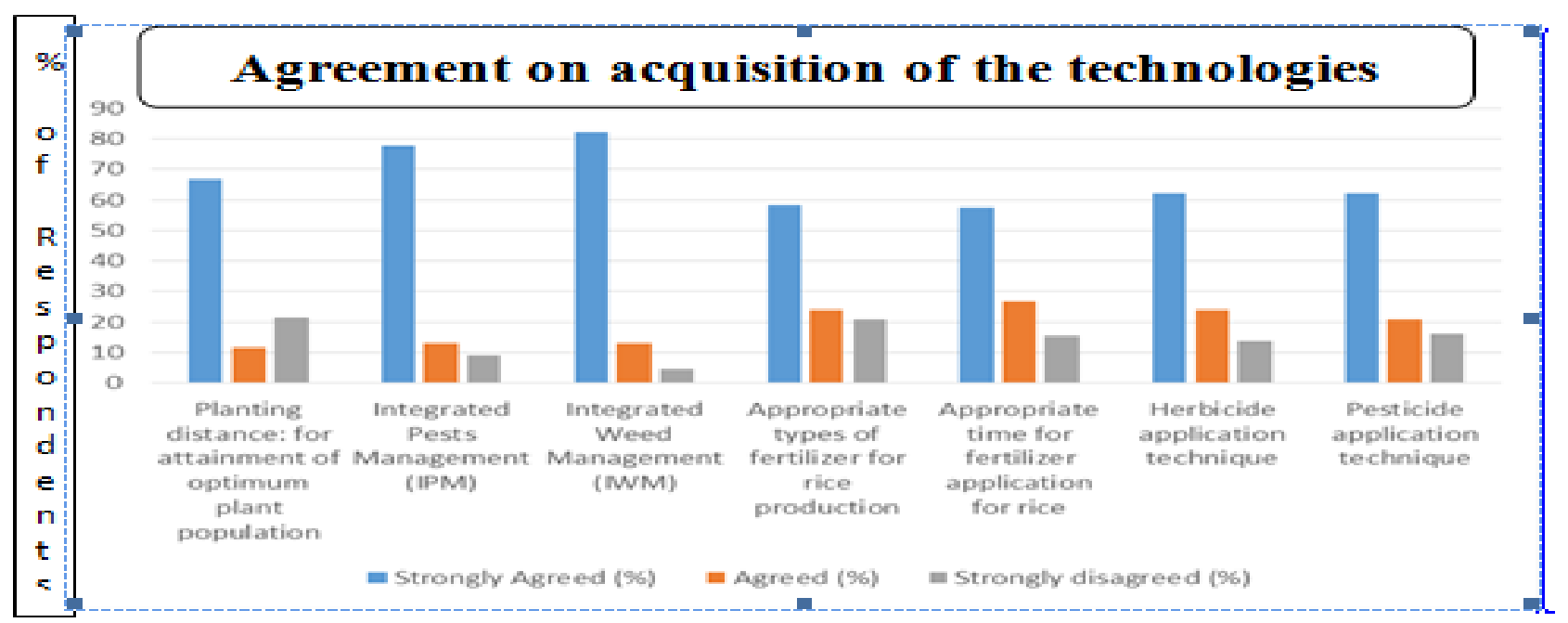

Figure 2: Agreement on acquisition of the technologies

Source: Field survey, 2017

\section{Conclusion and Recommendations}

The use of appropriate teaching methods provided a panacea to the emerging challenges in rice production. MTP was rated as the most favoured teaching methods to up scale the capabilities of small scale rice producers. Integrated pest and weed management were few up scaled capabilities of small scale rice producers in the study area. Since MTP was rated best as a teaching method or device for innovation dissemination. Extension organizations should place more premiums on MTP while attempting to expose farmers to emerging innovations on rice production in order to sustain or augment their capabilities for rice production on sustainable basis.

\section{References}

Abubakar, B. (2016). Nigeria spends one trillion on food importation. Paper presented at a sensitization seminar on Genetically Modified Organisms, GMOs, and Agricultural Biotechnology, organised for staff of Federal Ministry of Agriculture and Rural Development by Biotechnology Development Agency, in collaboration with other OFAB and National Biosafety Management Agency, in Abuja.

Food and Agriculture Organizations of the United Nations (2018). FAO in Nigeria, Nigeria at a glance. Downloaded November, 2018. www. fao.org/Nigeria/fao-in-Nigeria/Nigeria- at -a-glance

Food and Agriculture Organization of the United Nations (2014). Rice Market Monitor, Rice International Trade, Rice Utilization and Domestic Prices. Vol.XVII, Issue No. 4 pp 1. www.fao.org/economic/RMM or Rice-Network@fao.org

IndexMundi (2017). Nigerian Population Growth Rate, downloaded, February, 2018. Web address: https://www.indexmundi.com/nigeriapopulation_growth_rate 
Creative Commons User License: CC BY-NC-ND

Abstracted by: EBSCOhost, Electronic Journals Service (EJS), Google Scholar, Journal Seek, Scientific Commons,

Food and Agricultural Organization (FAO), CABI and Scopus
Journal of Agricultural Extension

Vol. 23 (2) April, 2019

ISSN(e): 24086851; ISSN(Print); 1119944X

http://journal.aesonnigeria.org

http://www.ajol.info/index.php/jae

Email: editorinchief@aesonnigeria.org

Kwara Agricultural Development Project (2015). Report of Crop Area Yield Survey, (2015)

Muhammad, A, Cuixia L., Sidra, G, Abdur R. Bushra, G., Shah S (2013). Problems faced by rice growing farmers and their behaviour to the government policies: A case from Pakistan, Agriculture and Health Care; Vol 3, No. 16,2013

National Population Census (2006). Kwara State Office, Ilorin

Nigerian Bureau of Statistics (2018). Contribution of Agriculture to the nominal gross domestic product (2018). www.nigerianstat.gov.ng Downloaded 21/01/2019

Oni T. O. (2014): Productive Sector Group, Economic Policy Research Department. Paper Submitted to Policy Engagement and ICT Department, Nigerian Institute of Social and Economic Research, Research Seminar Series (NRSS), NISER, Ibadan, Nigeria.

Organization for Economic Co-operation and Develpoment (OECD, 2015). The innovation policy platform, World Bank Groups (US) https://www.innovationpolicyplatform.org Downloaded 22/01/2019.

Oriakhi, H. and Okoedo-Okojie, D.U. (2013). Arable Crop Farmers Preference for Agricultural Information Sources and Adoption of Technology in Edo State, Nigeria. Department of Agricultural Economics, and Extension Services, School of Science and Technology, National Open University of Nigeria, Benin Study Centre.

Omofonmwan S. I. and M. A. Kadir (2017). Problems and Prospects of Rice Production in Central District of Edo State, Nigeria. Journal of Human Ecology Volume 22, (2) Pages 123-128

Riddle, W. C. and Xueda, S (2012). The role of education in technology use and adoption: Evidence from the Canadian workplaceand employee survey. Discussion Paper No. 6377, Feb. 2012

Thomas, B.U., Zhuany, J., Owuso,S.A. and Ayamba, E.C. (2017). Factors affecting the agricultural technologies adoption: The case of improved rice varieties in Northern Region of Ghana. Journal of Economics and Sustainable Development. Vol.8, No. 8 pp 137-148

Valentine, J.U (2018). Capacity Building for Sustainable Development, http://booksgoogle.com.ng/books18bn=178064816x pp 212 Downloaed 21/01/2019 